\title{
THE PLACE OF PROJECT MANAGEMENT IN THE FUNCTIONING OF AN ORGANISATION
}

\author{
Seweryn TCHÓRZEWSKI \\ Silesian University of Technology, Faculty of Organisation and Management, Institute of Management \\ and Logistics, seweryn.tchorzewski@polsl.pl, ORCID: 0000-0002-7039-1276
}

Purpose: The aim of this article is to present the place project management has and the role it plays in an organisation - the relations in projects carried out to create, maintain and reduce the potential of an organisation, understood as an opportunity to reach own operational targets.

Design/methodology/approach: The results received are due to an analysis of literature on the topic of this publication, as well as cases observed and analysed, discussions with the students and participants of trainings, as well as courses and workshops taught.

Findings: As a result of a thorough analysis, six typical cases in which the projects are carried out were identified. These cases were described in terms of their impact on the operational potential of an organisation.

Originality/value: The findings presented in this publication should complement the view on project management demonstrated at present - detachment of managerial processes from its organisation context, which is a regular practice of authors of publications in this field.

Keywords: project management, project in organisation, impact of project on organisation.

Category of the paper: 1 . Viewpoint, 2. Conceptual paper.

\section{Introduction}

Organisations willing to run a business have to constantly monitor the developments in the economy and adjust to them, or even set the tone of the industry. Otherwise they are doomed to gradual reduction and, in an extreme case, liquidation. When introducing these changes, they must reckon the possibility the risk associated with entering new areas, to enter of employees comfort zone or establish contact with new project stakeholders.

Despite the existence of many factors that disrupt the course of the organization's activities, they have no choice but to function in such a changing environment. According to the saying "who stands still, withdraws" - they have to react - make changes. Often, however, there is no 
awareness in organizations that the making of these changes can be carried out on a project basis, and thus with what work and activities it involves and what effects it will bring.

In this article, six typical situations in which project management may be applied in its entirety are presented. These are, respectively: building and reduction of the capacity of an organisation, project portfolio management, restoration and development, reorganisation.

\section{Project as a managerial tool}

The notion of a project was defined years ago. Its description can be found in many national and international sources, e.g. in Frame (Frame, 2002), Burk (Burke, 2003) or Heerkens (Heerkens, 2003). They reduce the project to an activity which:

- has a defined duration and clearly defined outcome,

- has conditions and should bring some long-term benefits,

- is accompanied by risk and, of course, how it is managed.

This operational approach is commonly understood and applied by organisations which implement projects. What is more, it usually forms the basis of creating whole management systems, not only single projects, but also their clusters (e.g. standards of PMI (A Guide...), IPMA (Wytyczne..., 2019), PRINCE2 (PRINCE 2.., 2018), APM (Highsmith, 2005) or an organisation's own solutions based on the mentioned standards).

Usually, it is accompanied by reorganisation of the internal procedure - depicting the project life cycle - from initiation, planning and implementation with monitoring to its closure (e.g. ISO 21500:2012 or Metodyki...; Trocki, 2017).

On the other hand, fully-fledged organisations in project management see a tool enabling them to achieving strategic objectives. They treat every project as a kind of "puzzle" allowing them to create activities vital to pursuing their strategy (Kerzner, 2005; Trocki, 2009). A commonly known example is the approach presented by Norton and Kaplan (Kaplan, Norton, 1992), which was subsequently applied in practice by many other managers (e.g. Karbownik (Karbownik, Wodarski, 2005)).

\section{Activities in an organisation realised through projects}

Beside these two mentioned areas - operational and strategic - there exist many different types of activities in which project management may prove to be particularly useful. To typical project situations, which can be pictured in the context of the functioning of any organisation, one may include, in the first place, the setting up of an organisation. The process of launching 
a new economic entity is in itself creative - we build an organisation from scratch, and in this respect, so to speak, from the definition, we can consider this activity as a project. We create a new environment, structure and relation with the surroundings; we obtain resources. As a result of this, project exploitation potential is created $(\mathrm{E})$, which will be used to achieve benefits after the process of its creation is completed (Fig. 1). This potential is used with various degrees of intensity and scale, depending on the changes which occur in the surroundings of the organisation, but they are not directly connected to project effects $(\mathrm{P})$.

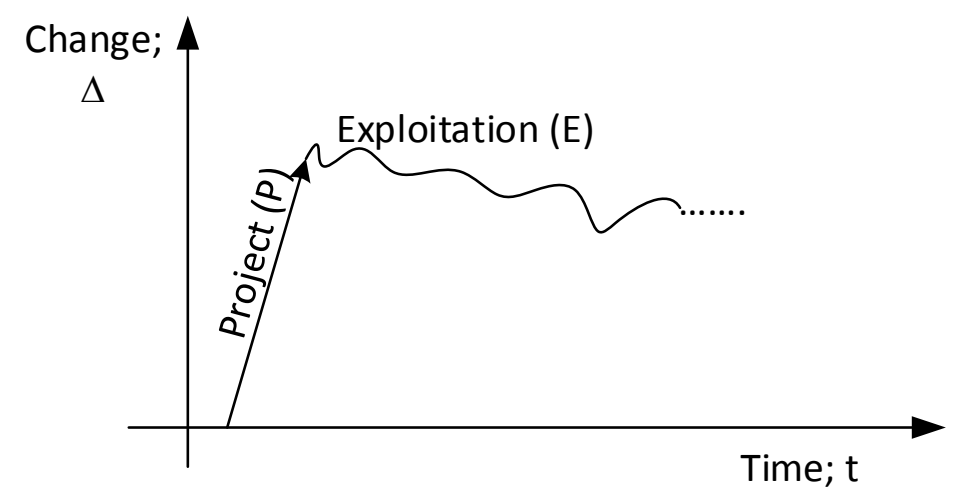

Figure 1. Creation as a project. Source: own work.

On the other side of the spectrum from the phenomenon of establishing an organisation is the phenomenon of reduction. In this case as well, we can implement actions through a project. This results from a simple reference to a juxtaposition: project = change; and yet a shutdown (or even reduction of activities) is also a change (Fig. 2). While approaching such a dramatic event in the life of an organisation, such as the shutdown of an organisation (or reduction of its activities), we have to deal with the necessity to coordinate different activities with a unique result - dismissing employees, settling up with clients, etc. However, contrary to a project starting a business, the result of a reduction project will be the liquidation of exploitation potential ( $E_{1}$ will amount to 0 ), and at best, the exploitation potential will be lower than the primary production potential $\left(\mathrm{E}_{1}<\mathrm{E}\right)$.

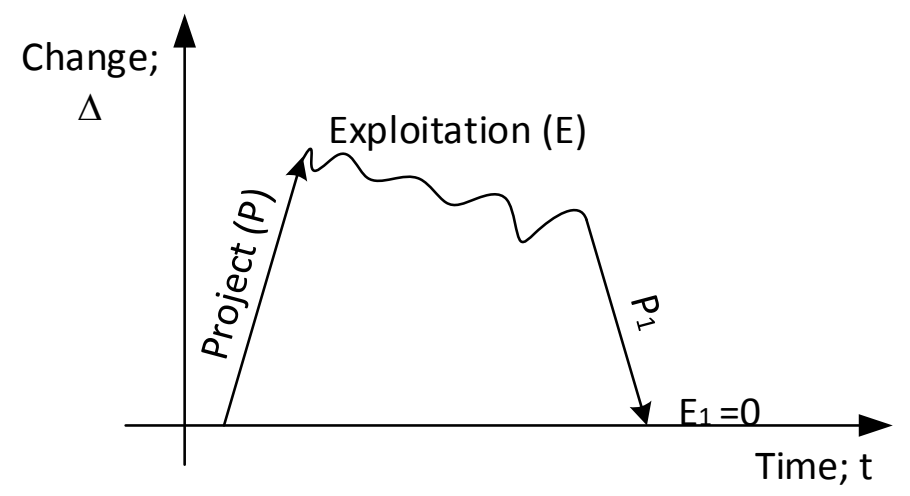

Figure 2. Reduction of activities as a project. Source: own work.

Another aspect of organisation functioning and using project management for this purpose is treating operational activities and carrying out assignments connected to them as projects (Fig. 3). Every contract and every agreement will be, in this case, an element of project portfolio 
$\mathrm{P} 1-\mathrm{P}_{\mathrm{n}}$. The number and size of the projects will differ according to the industry, scale of the organisation or the policy adopted for obtaining assignments, but in some way or another, carrying out projects should enable the organisation to reach the total established level of exploitation E, understood as defined by the organisation number of assignments, revenue, use of resources, etc. Projects included in such a portfolio will have some similarities, which does not automatically mean that they will be easy to manage. They will, however, have many common elements, which will make managing them easier. Typical example of such a situation is obtaining assignments by building companies or companies producing specialised machines or devices.

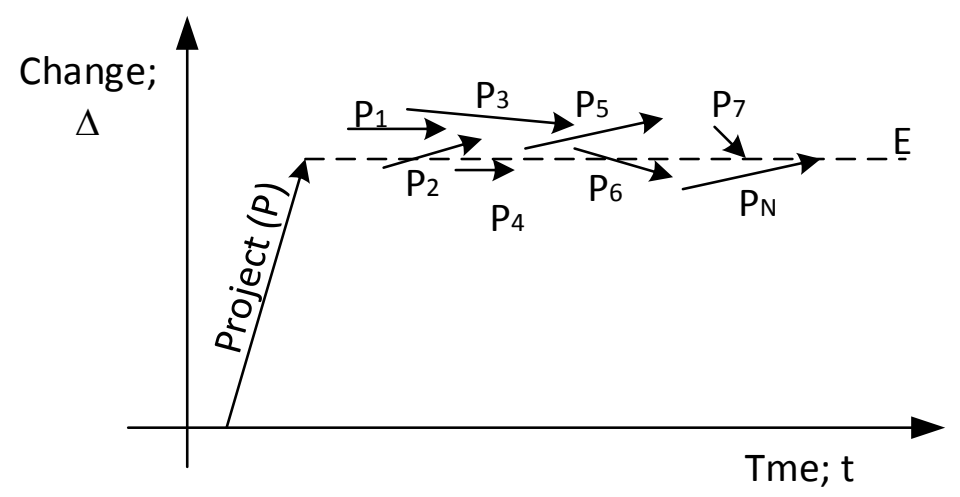

Figure 3. Operational activities in an organisation as a programme or project portfolio. Source: own work.

However, if we go back to an organisation as a place, where operational activities are conducted in a procedural manner and not in a project manner, then after the process of creation, thanks to which we achieve some exploitation potential E, its natural reduction or degradation always occurs with the passage of time, which is a result of the organisation's resources wearing out. An organisation endeavouring to stay on the market will be forced, every once in a while, to carry out activities related to restoration of the lost potential (Fig. 4). From this point of view, typical projects $\mathrm{P}_{1}$ which could be named here are, for example, repairs of objects (buildings, machines or devices) or replacing exploited/worn out objects with new ones of similar parameters. One has to be aware that it is extremely rare that the activities are carried out in such a manner that they mimic the mentioned system $100 \%$. Usually, project $\mathrm{P}_{1}$ results in exploitation potential $\mathrm{E}_{1} \neq \mathrm{E}$ (although in the illustration, they are of the same size), but the values will be rather similar. The reasons for such activities may differ; however, as an example, we can mention a commonly occurring phenomenon, which is a continuous technology change, which results not only in reconstruction of quantitative potential $\mathrm{E}$, but is also accompanied by simultaneous qualitative change. 


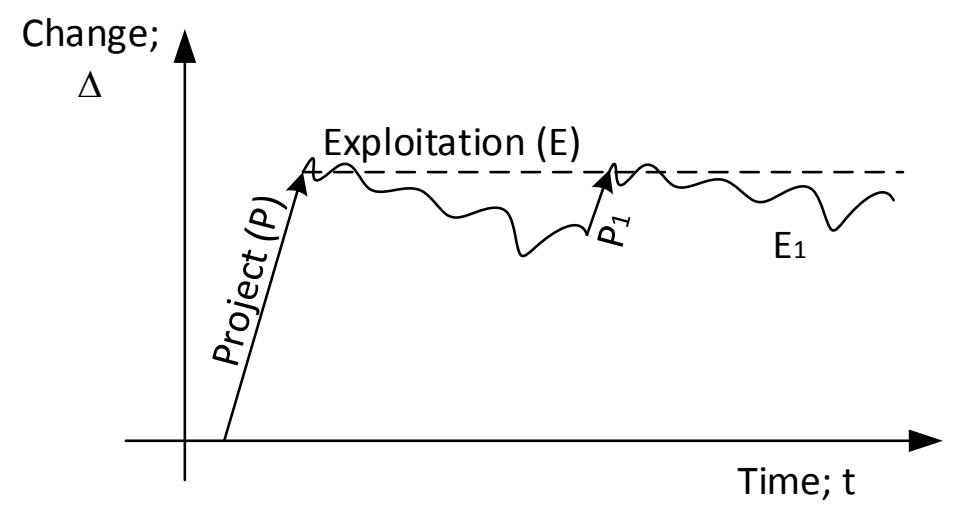

Figure 4. Recreation of production capacities in an organisation as a project. Source: own work.

For the reasons above, the previously mentioned recreation of production capacities in a pure form occurs rather rarely. We can, however, come across a situation in which the result of an introduced change (project $\mathrm{P}_{1}$ ) will be a change in the field of an organisation's exploitation potential $E_{1}$ (Fig. 5). And again, using typical examples, we can point out the replacement of a machine or a technological line or building a new object - a production hall or an office building for rent, or even the purchase of a company. To this category of projects, one has to count in $\mathrm{B}+\mathrm{R}$ projects, although their results are so different that a separate category of projects should be considered. To a certain extent, in particular in relation to these easier projects, such as the replacement of machines and devices, those projects are similar in character to the regenerating projects; however, in this case, the essence of these projects is achieving an effect in the form of exploitation potential $E_{1}$, which is radically different from the basis potential E.

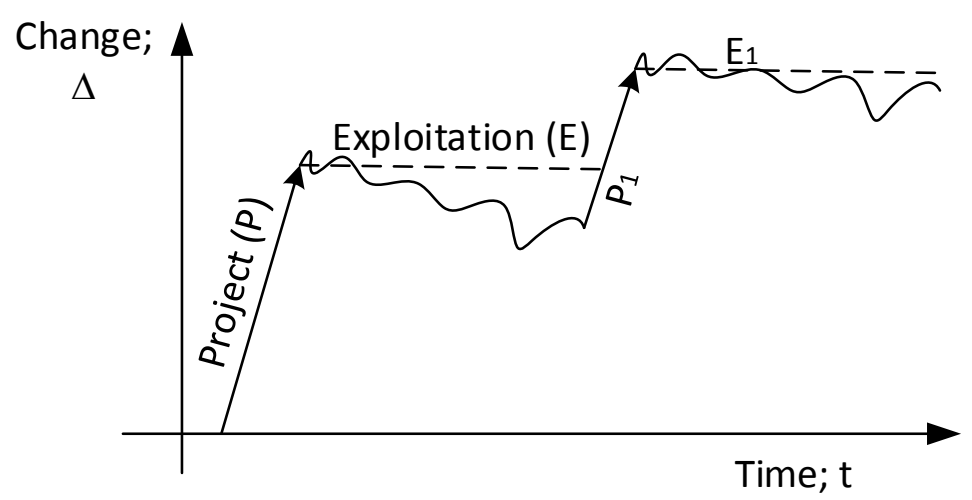

Figure 5. Increase of the exploitation potential of an organisation as a project. Source: own work.

A solution, which is a kind of twist on the theme of increasing the exploitation level, is reorganisation (Fig. 6). This activity basically fits into the definition of a project as a change. It is, at the same time, one of the toughest to execute, as carrying out a reorganisation project $\mathrm{P}_{1}$ is not designed to carry out activities, the effects of which will be similar in character to the activities carried out up to now, but quite the reverse. The effect $E_{1}$ of such a project will be new competence that has not existed up to the present in this organisation. As a consequence, there is a greater risk connected with maintaining the results of such a project in the future. Obviously, there are many well-known examples where such change brought about many 
benefits for an organisation, but for each positive example, we can find a company which was not able to carry out reorganisation in such a way that it would bring about the expected longterm effects.

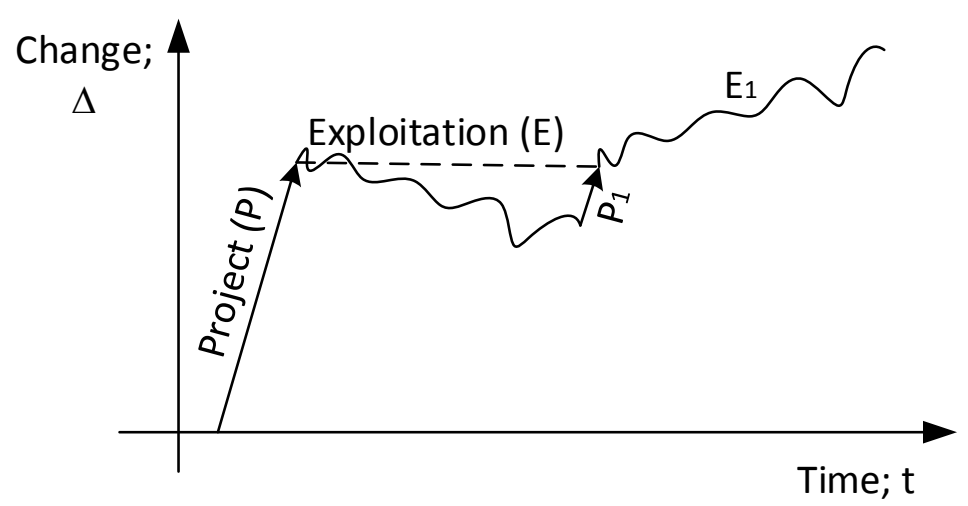

Figure 6. Reorientation as a project. Source: own work.

These particular activities rarely though occur in practice separately. Usually, in order to achieve the effective division of an organisation, it is essential to carry out different projects resulting from one another. Starting with the creation of new articles/products, their implementation, carrying out maintenance/recreation activities, we deal with a classic model of an organisation's life cycle; however, the pace at which the market environment is changing makes it necessary for the organisation to regularly renew its basic business area (Fig. 7). Without introducing such changes systematically, every organisation will struggle with the influence of the surroundings on its business activity.

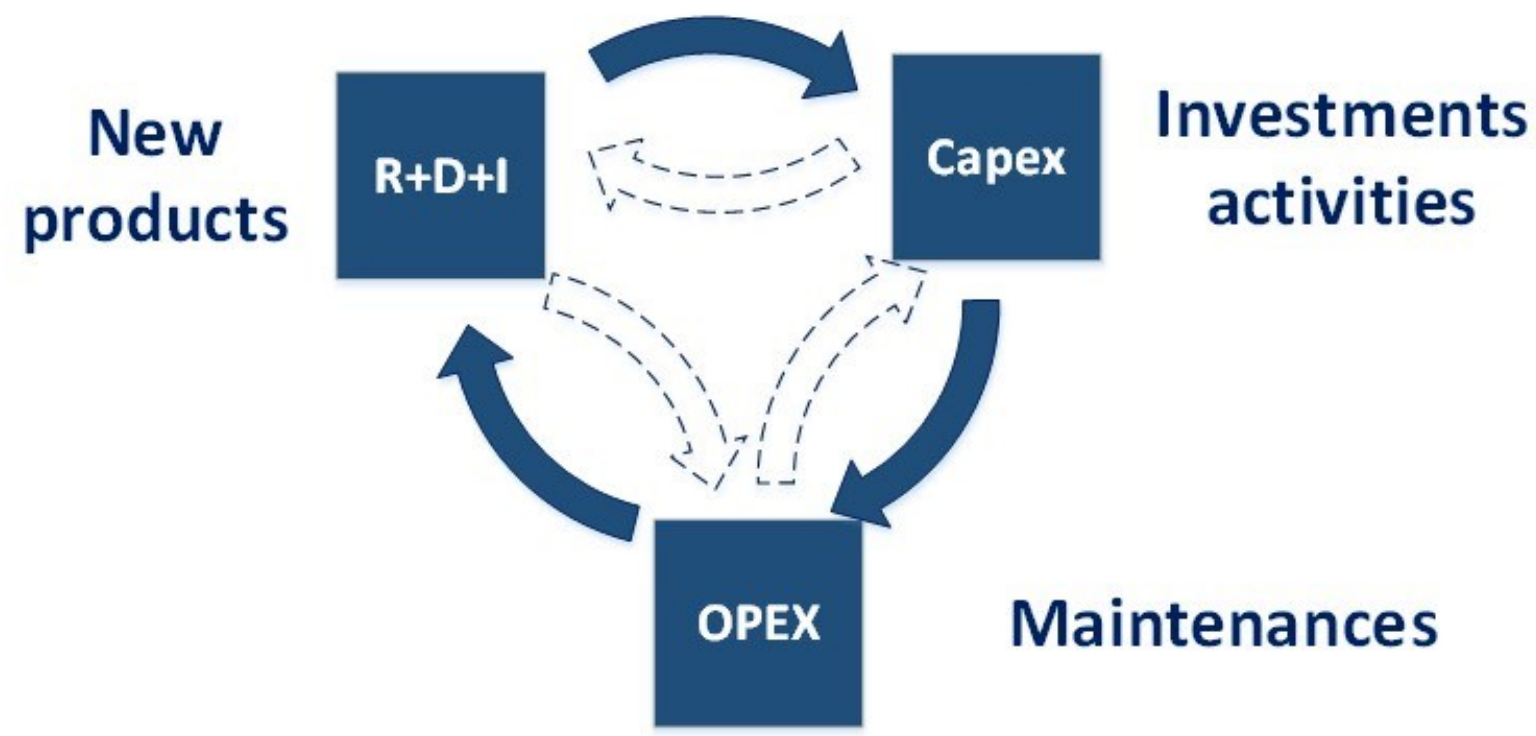

Figure 7. Projects in the life cycle of an organisation. Source: own work. 


\section{Summary}

Taking into consideration the above-mentioned reflections, one needs to take note of the following aspects of the discussed issue:

1. Organisations which are willing to function efficiently in their environment have to introduce changes systemically, and the tools which facilitate the introduction of changes, and therefore achieving set objectives, are projects.

2. In its pure form, the solutions listed in the first part of the article occur quite rarely. A selected project may be assigned to different generic groups. Projects from the $B+R$ portfolio can simultaneously be a project aiming to increase productions level as well as to improve the quality of the offer. The key is to determine the effects/benefits which will be achieved due to project implementation.

3. Differentiation of the project types does not increase the work comfort of the project managers or management boards, but points out the necessity of ordering and systematising the project management process in organisations. It also indicates the need to notice various types of projects in these organisations and, therefore, apply flexible rules for managing them.

\section{References}

1. A Guide to the Project Management Body of Knowledge. PMBOK Guide. PMI (MT\&DC).

2. Burke, R. (2003). Project Management. Wiley.

3. Cleland, D.I., Bursic, K.M., Puerzer, R., Vlasak, Y. (1998). Project management casebook. PMI.

4. Frame, D.J. (2002). The new project management. San Francisco: Jossey-Bass.

5. Heerkens, G.R. (2003). Jak zarzadzać projektami. Warszawa: RM.

6. Highsmith, J. (2005). APM: Agile Project Management. Warszawa: MIKOM.

7. Kaplan, R.S., Norton, D.P. (1992). The Balanced Scorecard - Measures that Drive Performance. Harvard Business Review.

8. Karbownik, A., Wodarski, K. (2005). Zastosowanie Strategicznej Karty Wyników w górnictwie węgla kamiennego. Krynica: Szkoła Ekonomiki i Zarządzania w Górnictwie.

9. Kerzner, H. (2005). Advanced Project Management. Gliwice: Helion.

10. Praca zbiorowa (2011). Metodyki zarządzania projektami. Warszawa: BIZARRE.

11. PRINCE 2 - skuteczne zarzadzanie projektami (2018). TSO.

12. Trocki, M. (ed.) (2009). Strategiczne zarzadzanie projektami. Warszawa: BIZARRE.

13. Trocki, M. (ed.) (2017). Metodyki i standardy zarzadzania projektami. Warszawa: PWE.

14. Wytyczne Kompetencji Indywidualnych IPMA - ICB 4.0 (2019). Warszawa: IPMA Polska. 